\title{
Antioxidant Activity and Phytochemical Screening of Some Sansevieria Plants
}

\author{
T. M. Sarjani, A. L. Mawardi*, E. S. Pandia, A. R. S. Siregar \\ Biology Education Department, Faculty of Teacher Training and Education \\ Samudra University \\ Nanggroe Aceh Darussalam, Indonesia \\ *mawardibio@unsam.ac.id
}

\begin{abstract}
Sansevieria plants are known as ornamental plants that are able to ward off free radicals in nature, this plant allegedly potential as antioxidant. This study aimed to determine the antioxidant activity of three etanol plant extracts from Sansevieria genus, Sansevieria trifasciata, Sansevieria green tiger and Sansevieria zeylanica, were tested by using the 1,1-diphenyl2-picryhydrazyl (DPPH) radical-scavenging assay. This method measuring the $\mathrm{IC}_{50}$ of the extracts. The plant extracts that point the highest antioxidant activity were Sansevieria trifasciata, the most potential as an alternative to antioxidant substitutes for vitamin $\mathrm{C}$ with an $\mathrm{IC}_{50}$ value of $9.44 \mathrm{ppm}$. This result would be promising sources for developing anticancer agents. Flavonoids are the principle elements for toxicity activity and are promising compounds for use as antioxidant agents.
\end{abstract}

\section{Keywords—antioxidant activity, DPPH, Sansevieria}

\section{INTRODUCTION}

Over their life span, the organism is exposed to the effects of free radicals, the generation of oxidizing agents caused by environmental pollutants, lifestyle, pesticides and cigarette smoke [1,2].

Two of the numerous chemical entities such as ROS (Reactive Oxygen Species) and RNS (Reactive Nitrogen Species) agents that act as oxidizing agents have shown causing cross-linking and protein modification, lipid peroxidation, polypeptide backbone, cross-linking in DNA causing intrastrand and interstrand DNA [3,4]. All these processes over time will cause serious effects, such as arteriosclerosis, ageing, blind spot, long- term inflammation; as well as cancers, diabetes mellitus, liver and neurodegenerative disease, and cardiovascular disorder $[5,6]$.

Humans have their own endogenous defense system to ward off free radical compounds formed by various enzymes, such as catalase (CAT), glutathione peroxidase (GPX), and superoxide dismutase (SOD) which form antioxidant compounds, however, their effectiveness is still lacking due to the disproportionate number of free radical attacks from the environment that enter the body, therefore exogenous antioxidant compounds are needed $[7,8]$.
Antioxidants from outside the body (exogenous) can be obtained naturally from nature, such as plants that function as antioxidants and antioxidants synthetically. The use of synthetic antioxidants is carcinogenic and in a certain period can cause poisoning to the body $[9,10]$. The use of natural antioxidants from certain plants has been developed. Plants with phenolic content such as flavonoids, alkaloids, saponins, tannins, steroids / triterpenoids can inhibit exposure to free radicals $[11,12]$.

Based on the metabolite compounds contained in plants from the genus Sansevieria, it is thought to have antioxidant activity. Sansevieria roxburghiana Schult is stated to have active antioxidant compounds in the form of alkaloid compounds, saponins, flavonoids, phenols, and steroids by phytochemical tests with $\mathrm{IC}_{50} 1,45 \mu \mathrm{g} / \mathrm{mL}[13,4]$. Followed by Sansevieria Masoniana Chahin the extract contains flavonoid and saponin compounds with $\mathrm{IC}_{50} 97,902 \mu \mathrm{g} / \mathrm{mL}$ [15], and by Sanseveria Cylindrica shows the phytochemical content of alkaloids, triterpenoids, flavonoids and steroids with $\mathrm{IC}_{50} 99,66$ $\mu \mathrm{g} / \mathrm{mL}$ which have the ability as antioxidants $[16,17]$.

However, information about the antioxidant activity of several other Sansevieria species and also the comparison of their effectiveness, namely Sansevieria trifasciata, Sansevieria green tiger, and Sansevieria zeylanica is not yet known, even though the knowledge of these plants is important to know so that it can make the plant genus Sansevieria a plant source of antioxidants. The use of Sansevieria plants in research is also based because these plants are easy to find in tropical regions such as Indonesia, so they are efficient to be used as research samples.

The high yield of antioxidants produced by the Sansevieria plant so that it can protect body cells from exposure to UV rays, free radical compounds, and with the aim of reducing the use of synthetic antioxidants promped us to examine 3 ethanol extracts from 3 species of Sansevieria to see their antioxidant activity and make comparisons. The antioxidant assays selected for this study is 1,1-diphenyl-2-picrylhydrazyl (DPPH), These assay are primarily based totally on electron transfer (ET) response principle, where the colour change will act as an 
indicator to the potential of antioxidant in reducing the radicals [18].

\section{METHODS}

\section{A. Plant Material}

Samples of fresh tongue-in-law leaves were collected from Meurandeh Village, Langsa city of Aceh Province Indonesia between June and July 2020. Samples were cleaned and then dried without direct sun exposure for 2 days. After drying, let it air the leaves are crushed and stored inside a closed container. The purpose of drying is to prevent enzymatic reactions (microbial activity) and prevent the growth of fungi so that they can be stored longer and are less easily damaged and their chemical composition does not change.

\section{B. Extraction}

The extraction method used is a maceration method with using $96 \%$ ethanol solvent. Each leaf powder of each species Sansevieria as much as 500 gr macerated with 2 L of $96 \%$ ethanol in the container closed for $2 \times 24$ hours with stirring occasionally. Then the macerate is filtered and pressed evaporation using a rotary evaporator at a temperature of $100^{\circ}$ $\mathrm{C}$ to separate extract with solvent. Next evaporated with a water bath until formed a viscous extract.

\section{Phytochemical Analysis}

Flavonoids, saponins, terpenoids, steroids, alkaloids, and tannins were tested on the extract of the leaves. The flavonoid test was carried out with $\mathrm{H}_{2} \mathrm{SO}_{4}$, the saponin test was carried out with distilled water, alcohol, and HCL, the terpenoid test used the Liebermann-Burchard reagent, the steroid test was carried out with the Liebermann-Burchard reagent, the alkaloid test was carried out with HCL, Bouchardart reagent and Meyer reagent, the tannin test was carried out with $\mathrm{FeCl}_{3}$ [19].

\section{Antioxidant Activity Assay for DPPH Free Radical Scavenging Activity}

Antioxidant activity was tested using the DPPH method which made into a control solution in the form of $\mathrm{OH}$ ethanol, vitamin $\mathrm{C}$ solution (positive control) was made into concentrations of $2,4,6,8,10 \mathrm{ppm}$, and the third series solution of the in-law's tongue leaf extract, each series solution was made into concentrations of $2,4,6,8,10 \mathrm{ppm}$; then, each solution is left for 30 minutes in a dark room; Then, measure the absorbance at a wavelength of $517 \mathrm{~nm}$ with a UV-VIS spectrophotometer. As blank was used a solution prepared mixing $1 \mathrm{~mL}$ DPPH solution with ethanol p.a and reading at the same wavelength.

\section{E. Data Analysis}

The percent inhibition was calculated from the following equation :

$\%$ Inhibition $=[$ Absorbance of control - Absorbance of test sample] $\times 100$
Then, the data were analyzed by using the Linear Regression with Microsoft Excel test.

\section{RESULTS AND DISCUSSION}

This study used three species of Sansevieria plants consisting of Sansevieria trifasciata, Sansevieria green tiger and Sansevieria Zeylanica. First, leave Sansevieria dry and air dry for two days as much as 500 grams of Simplicia. After maceration and evaporation of each extract of the leaves of the tongue-in-law as much as $200 \mathrm{ml}$ was used for the antioxidant test. Before doing the antioxidant test, first, the secondary metabolites were determined by using phytochemical tests on leaf extracts. The results of the phytochemical test can be seen in table 1.

TABLE I. RESULT FROM PHYTOCHEMICAL SCREENING

\begin{tabular}{|c|c|c|c|}
\hline Phytocompounds & S. trifasciata & S. green tiger & S. zeylanica \\
\hline Flavonoid & $(+)$ & $(+)$ & $(+)$ \\
\hline Saponin & $(+)$ & $(+)$ & $(+)$ \\
\hline Terpenoid & $(-)$ & $(-)$ & $(-)$ \\
\hline Steroid & $(+)$ & $(+)$ & $(+)$ \\
\hline Alkaloid & $(-)$ & $(-)$ & $(-)$ \\
\hline Tanin & $(-)$ & $(-)$ & $(-)$ \\
\hline
\end{tabular}

Based on the results of phytochemical tests, the three Sansevieria species were positive for the same secondary metabolites in the form of flavonoids, steroids, and saponins.

The determination of the value of antioxidant activity in the extract of the Sansevieria plant uses the DPPH (1,1-diphenyl-2picrihidrazil) free radicals absorption method. The reason for using this method is due to its simple, fast, and proven accuracy. The reduction of free radicals by these antioxidant compounds will form DPPH radicals to become stable and experience a reduction in color intensity, thus indicating an increase in the antioxidant activity from the extract [20,21].

Based on tables 2, 3, and 4 it can be seen that the greater the concentration of the extract of the tongue-in-law leaves that is tested for its antioxidant activity, the smaller the absorbance value and the greater the $\%$ inhibition value. At a concentration of $10 \mathrm{ppm}$, the $\%$ inhibition was found to be the greatest and at a concentration of $2 \mathrm{ppm}$ had the smallest $\%$ inhibition. Likewise, with vitamin $\mathrm{C}$ solution which at a concentration of $10 \mathrm{ppm}$ found the highest $\%$ inhibition, namely $62.08 \%$, and at a concentration of $2 \mathrm{ppm}$ had the smallest\% inhibition, namely $47.99 \%$. Thus it shows that the higher the leaf extract concentration or the concentration of vitamin $\mathrm{C}$ given, the higher the number of antioxidants contained in the leaf extract and vitamin $\mathrm{C}$ concentrations so that it has the better ability to reduce free radicals. The relationship between the $\mathrm{IC}_{50}$ value and the $\%$ of attenuation is that if the $\mathrm{IC}_{50}$ value is smaller, the $\%$ of attenuation is greater, which means that the extract contains a lot of potential antioxidant compounds and the antioxidant activity of an extract against free radical reduction is getting better because it can reduce more free radicals. 
The flavonoids contained in the Sansevieria extract have the ability as antioxidants because there are hydroxyl groups can give one of its hydrogen atoms to a free radical compound so that phenolic compound radicals can reduce free radicals. On the other hand, if the IC50 value is large, the \% attenuation is small, which means that the antioxidant compounds are in small amounts and have less good antioxidant activity [10,22].

TABLE II. Absorbance MEASUREMENT OF SANSEVIERIA TRIFASCIATA LEAF EXTRACTS With COMPARATIVE Vit C

\begin{tabular}{|c|c|c|c|c|c|c|}
\hline \multirow{2}{*}{ No. } & \multirow{2}{*}{ Control (EtOH, Abs) } & \multirow{2}{*}{ Concentration (ppm) } & \multicolumn{2}{|c|}{ Absorbance } & \multicolumn{2}{|c|}{$\%$ Inhibisi } \\
\hline & & & Vitamin $C$ & Sansevieria $T$ & Vitamin $C$ & Sansevieria $T$ \\
\hline 1 & \multirow{5}{*}{0,298} & 2 & 0,155 & 0,213 & 47,99 & 28,52 \\
\hline 2 & & 4 & 0,127 & 0,195 & 57,38 & 34,56 \\
\hline 3 & & 6 & 0,119 & 0,169 & 60,07 & 43,29 \\
\hline 4 & & 8 & 0,116 & 0,164 & 61,07 & 44,97 \\
\hline 5 & & 10 & 0,113 & 0,146 & 62,08 & 51,01 \\
\hline
\end{tabular}

TABLE III. AbSORBANCE MEASUREMENT OF SANSEVIERIA GREEN TIGER LEAF EXTRACTS With COMPARATIVE Vit C

\begin{tabular}{|c|c|c|c|c|c|c|}
\hline \multirow{2}{*}{ No. } & \multirow{2}{*}{ Control (EtOH, Abs) } & \multirow{2}{*}{ Concentration (ppm) } & \multicolumn{2}{|c|}{ Absorbance } & \multicolumn{2}{|c|}{ \% Inhibisi } \\
\cline { 3 - 7 } & & & Vitamin C & Sansevieria GT & Vitamin C & Sansevieria GT \\
\hline 1 & 2 & 0,155 & 0,241 & 47,99 & 19,13 \\
\hline 2 & \multirow{3}{*}{0,298} & 0,127 & 0,241 & 57,38 & 19,13 \\
\hline 3 & & 0,119 & 0,23 & 60,07 & 22,82 \\
\cline { 3 - 7 } & & 8 & 0,116 & 0,222 & 61,07 & 25,50 \\
\cline { 3 - 7 } & & 10 & 0,113 & 0,21 & 62,08 & 29,53 \\
\cline { 3 - 7 } & & & & &
\end{tabular}

TABLE IV. ABSORBANCE MEASUREMENT OF SANSEVIERIA Trifasciata LEAF EXTRACTS With COMPARATIVE Vit C

\begin{tabular}{|c|c|c|c|c|c|c|}
\hline \multirow{2}{*}{ No. } & \multirow{2}{*}{ Control (EtOH, Abs) } & \multirow{2}{*}{ Concentration (ppm) } & \multicolumn{2}{|c|}{ Absorbance } & \multicolumn{2}{|c|}{ \% Inhibisi } \\
\hline & & & Vitamin $C$ & Sansevieria $Z$ & Vitamin $C$ & Sansevieria $Z$ \\
\hline 1 & \multirow{5}{*}{0,298} & 2 & 0,155 & 0,216 & 47,99 & 27,52 \\
\hline 2 & & 4 & 0,127 & 0,212 & 57,38 & 28,86 \\
\hline 3 & & 6 & 0,119 & 0,201 & 60,07 & 32,55 \\
\hline 4 & & 8 & 0,116 & 0,198 & 61,07 & 33,56 \\
\hline 5 & & 10 & 0,113 & 0,155 & 62,08 & 47,99 \\
\hline
\end{tabular}

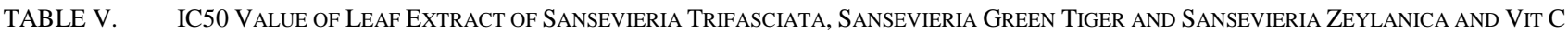

\begin{tabular}{|c|l|l|l|}
\hline No & \multicolumn{1}{|c|}{ Sample } & \multicolumn{1}{|c|}{ Straight-line equations } & \multicolumn{1}{|c|}{ IC $_{\mathbf{5 0}}$ values } \\
\hline 1. & Vitamin C & $\begin{array}{l}\mathrm{y}=1,594 \mathrm{x}+48,154 \\
\mathrm{R}^{2}=0,778\end{array}$ & 1,16 \\
\hline 2. & Sansevieria trifasciata & $\begin{array}{l}\mathrm{y}=2,768 \mathrm{x}+23,859 \\
\mathrm{R}^{2}=0,968\end{array}$ & 9,44 \\
\hline 3. & Sansevieria green tiger & $\begin{array}{l}\mathrm{y}=1,359 \mathrm{x}+15,067 \\
\mathrm{R}^{2}=0,938\end{array}$ & 25,70 \\
\hline 4. & Sansevieria Zeylanica & $\begin{array}{l}\mathrm{y}=2,282 \mathrm{x}+20,403 \\
\mathrm{R}^{2}=0,782\end{array}$ & 12,97 \\
\hline
\end{tabular}

An antioxidant is included in the very strong class if the IC value is much less than $50 \mathrm{ppm}$, a strong antioxidant if it's far 50 -a hundred ppm, slight if it's far $101-250 \mathrm{ppm}$, is weak if it's far 251-500 ppm and does now no longer characteristic an antioxidant with a cost of extra than $500 \mathrm{ppm}$. From table 2, 3, and 4 it can be seen that at each concentration there is an increase in\% inhibition, where at a concentration of $2 \mathrm{ppm}$ the inhibition value of the three extracts is $28.52 \%, 19.13 \%$, $27.52 \%$, at a concentration of $4 \mathrm{ppm}$. with\% inhibition of $34.56 \%, 19.13 \%$, and $28.86 \%$, the $\%$ inhibition continued to increase followed by an increase in extract concentration. The highest\% inhibition was $51.01 \%$ with a concentration of 10 $\mathrm{ppm}$ in the Sansevieria trifasciata species. From the curve that continues to increase, the $R_{2}$ value of the three extracts is 0.9678, 0.9389, and 0.782, which are close to +1 (positive value). It shows that $\%$ free radical reduction has a correlation with the three extracts of the Sansevieria leaves. Where the higher the concentration tested, the higher the\% of free radical reduction.

From table 2,3 and 4 it can also be seen that at each concentration of vitamin $\mathrm{C}$ there is an increase in\% inhibition, where at a concentration of $2 \mathrm{ppm}$ the inhibition value of vitamin C is $47.99 \%$, at a concentration of 4 ppm the inhibition 
of vitamin $\mathrm{C}$ is 57.38 , continues to occur. an increase in $\%$ inhibition followed by an increase in the concentration of vitamin $\mathrm{C}$ given. The highest in percent inhibition was at a concentration of $10 \mathrm{ppm}$ which was $62.08 \%$. From the increasing curve, the $\mathrm{R}_{2}$ value of the vitamin $\mathrm{C}$ solution is 0.778 which is close to +1 (positive value). This shows that the $\%$ free radical reduction has a correlation with the vitamin $\mathrm{C}$ solution. Where the higher the concentration tested, the higher the $\%$ free radical reduction.

The $\mathrm{IC}_{50}$ value can be determined using the Least square equation. Making graphs and looking for linear regression equations using the Microsoft Excel test. The following is a table of the results of calculating the $\mathrm{IC}_{50}$ value of the three extracts leaves and vitamin $\mathrm{C}$.

From table 5 , it can be seen that the results of the $\mathrm{IC}_{50}$ value of the three extracts of the tongue-in-law leaves are still lower than the $\mathrm{IC}_{50}$ value of vitamin $\mathrm{C}$. This indicates that vitamin $\mathrm{C}$ as a positive comparison is still better than the three extracts of the Sansevieria leaves as an antioxidant at the same concentration. ( 2 ppm, 4 ppm, 6 ppm, 8 ppm, 10 ppm), but the Sansevieria trifasciata species has the most potential as a source of antioxidants with the smallest $\mathrm{IC}_{50}$ value of 9.44 which is included in the very strong antioxidant category.

\section{CONCLUSIONS}

Based on the results of the research and the data obtained, it can be concluded that Sansevieria trifasciata leaf extract has very strong antioxidant activity and has the most potential as an alternative to antioxidant substitutes for vitamin $\mathrm{C}$, with an $\mathrm{IC}_{50}$ value of $9.44 \mathrm{ppm}$. From this research, it can also be seen that flavonoids are the main factors for toxicity activity and are promising compounds to be used as antioxidant agents.

\section{ACKNOWLEDGMENT}

We thank to the laboratory of the faculty of biology, University of Syiah Kuala for the facilities and opportunities that have been given.

\section{REFERENCES}

[1] B. A. S. M. Esfahani, M. Mirmoghtadaei, and S. B. Anaraki, "Oxidative stress and aging " Immunol. Aging, pp. 323-338, 2014

[2] O. M. Mosquera, Y. M. Correra, and J. Niño, "Antioxidant activity of plant extracts from Colombian flora” Brazilian J. Pharmacogn., vol. 19, no. 2 A, pp. 382-387, 2009.

[3] H. Pelicano, D. Carney, and P. Huang, "ROS stress in cancer cells and therapeutic implications" Drug Resistance Updates (2004) vol. 7, pp. 97-110, 2004

[4] B. Van Houten, V. Woshner, and J. H. Santos, "Role of mitochondrial DNA in toxic responses to oxidative stress" DNA Repair, vol. 5, pp. $145-152,2006$
[5] C. Gonc, T. Dinis, and M. T. Batista, "Antioxidant properties of proanthocyanidins of Uncaria tomentosa bark decoction : a mechanism for anti-inflammatory activity" Phytochemistry, vol. 66, pp. 89-98, 2005

[6] H. W. Kim, A. Murakami, M. V. Williams, H. Ohigashi, and H. W. Kim, "Mutagenicity of reactive oxygen and nitrogen species as detected by co-culture of activated inflammatory leukocytes and AS52 cells inflammatory leukocytes , are mutagenic in the biological" Carcinogenesis, vol.24 vol. 24, no. 2, pp. 235-241, 2003.

[7] F. Aqil, I. Ahmad, and Z. Mehmood, "Antioxidant and free radical scavenging properties of twelve traditionally used Indian medicinal plants” Turkish J. Biol., vol. 30, no. 3, pp. 177-183, 2006.

[8] J. M. C. Gutteridget, "Oxygen Free Radicals and Iron in Relation to Biology and Medicine: Some Problems and Concepts" Archives Of Biochemistry And Biophysics,vol. 246, no. 2, p. 9861, 1986.

[9] L. Jin, Y. Zhang, L. Yan, Y. Guo, and L. Niu, "Phenolic compounds and antioxidant activity of bulb extracts of six Lilium species native to China" Molecules, vol. 17, no. 8, pp. 9361-9378, 2012.

[10] S. P. Wong, L. P. Leong, J. Hoe, and W. Koh, "Antioxidant activities of aqueous extracts of selected plants" Elsevier ,no. August, 2005

[11] R. L. Prior, "Fruits and vegetables in the prevention of cellular oxidative damage 1 - 5," Am J Clin Nutr, vol. 78, pp. 570-578, 2003.

[12] C. Kaur and H. C. Kapoor, "Anti-oxidant activity and total phenolic content of some Asian vegetables" Journal of Food Science and Technology, pp. 153-161, 2002

[13] P. Molyneux, "The Use of the Stable Free Radical Diphenylpicrylhydrazyl (DPPH) for Estimating Antioxidant Activity" Songklanakarin J. Sci. Technol., vol. 26, no. December 2003, pp. 211-219, 2004.

[14] P. Mag, R. Maheshwari, C. S. Shreedhara, P. R. Polu, and R. S Managuli, "Characterization of the Phenolic Compound, Gallic Acid from Sansevieria roxburghiana Schult and Schult . f . Rhizomes and Antioxidant and Cytotoxic Activities Evaluation" Pharmacognosy Magazine, vol 13, pp. 693-699, 2017.

[15] A. R. S. Siregar, "Analysis Of Antioxidant Activity Of Lidah Mertua Leaves ( sansevieria masoniana Chahin ) extract Using DPPH," Jurnal Jeumpa, vol. 7, no. 1, pp. 310-318, 2020.

[16] Z. M. Thu, K. K. Myo, H. T. Aung, and C. Armijos, "Flavonoids and Stilbenoids of the Genera Dracaena and Sansevieria: Structures and Bioactivities." Molecules, vo. 25, pp. 2608, 2020.

[17] R. Pratama, "Potensi Antioksidan Dan Toksisitas Ekstrak Daun Sansevieria Cylindrica," 2010.Departemen Biokimia Fakultas Matematika Dan Ilmu Pengetahuan Alam Institut Pertanian Bogor 2010.

[18] K. Marxen, K. H. Vanselow, S. Lippemeier, R. Hintze, A. Ruser, and U. Hansen, "S7102080.Pdf," Sensors, vol. 7, pp. 2080-2095, 2007.

[19] W. Brand-Williams, M. E. Cuvelier, and C. Berset, "Use of a free radical method to evaluate antioxidant activity" LWT - Food Sci. Technol., vol. 28, no. 1, pp. 25-30, 1995.

[20] I. I. Koleva, T. A. Van Beek, J. P. H. Linssen, A. De Groot, and L. N. Evstatieva, "Screening of Plant Extracts for Antioxidant Activity a Comparative Study on Three Testing Methods - Koleva - 2001 Phytochemical Analysis - Wiley Online Library” Phytochem. Anal., vol. 13, pp. 8-17, 2002.

[21] V. Katalinic, M. Milos, T. Kulisic, and M. Jukic, "Screening of 70 medicinal plant extracts for antioxidant capacity and total phenols" Food Chem., vol. 94, no. 4, pp. 550-557, 2006.

[22] P. Mahakunakorn, M. Tohda, Y. Murakami, K. Matsumoto, and H Watanabe, "Antioxidant and free radical-scavenging activity of Chotosan and its related constituents" Biol. Pharm. Bull., vol. 27, no. 1, pp. 38-46, 2004. 